\title{
USING AHP FOR THE VALUATION OF A COMPANY: COMBINING SUCCESS FACTORS AND FINANCIAL NUMBERS
}

\author{
Matthias Amen \\ Institut für Unternehmensrechnung und Controlling \\ Universität Bern \\ Engehaldenstrasse 4, CH-3012 Bern - Switzerland \\ matthias.amen@iuc.unibe.ch
}

Keywords: valuation of a company, accounting, finance, success factors, benchmarking

Summary: Considering the fundamental meaning of the price as an exchange relation between certain goods, the value of a company can be expressed relative to the value of competitor companies. Assuming that the value of a company derives from the existence of success factors we have to compare the company and its competitors with respect to them. As the success factors are soft criteria the AHPtechnique (Saaty, 1990) can be recommended to measure competitive advantages arising from the use of these success factors and to determine an overall relative value of a company. Furthermore it is possible to integrate the commonly-used financial valuation formulas. Assuming that the values of the competitors are known in monetary units (e.g. stock capitalization), we are able to determine a range of estimates of the value of a company in monetary units.

\section{Economic background}

Generations of experts have been occupied with the question of the value of a company. The literature for this topic fills whole library walls (e.g. Ballwieser, 1995; Drukarczyk and Schwetzler, 1998; Born, 1995; Copeland, Koller and Murrin, 1994; Damodaran, 1994; Bodie, Kane and Marcus, 1996, p. 521-559; Mandl and Rabel, 1997; Loderer, 2000, pp. 585-751). Therefore it is impossible to give the formula for the "right" valuation of companies in this paper. The aim of this paper is to outline an approach, which derives from the fundamental meaning of the price as an exchange relation between goods - an idea which often seems to be missed in modern sophisticated financial valuation formulas: A company will not necessarily be valued in monetary units, but will be valued in comparison to one or several other companies - in the following this is called the "relative value" of a company. Later it will be shown that the relative value can be transformed easily into monetary units.

The valuation of goods is one of the very early questions of the economic science (for the managementoriented theory of value see Bretzke, 1974, pp. 17-41). Gossen, 1854, was the first, who stated that the value of a good is determined by its marginal utility to an individual and therefore of subjective nature. Prices only represent the exchange relation of the esteem of goods. Accordingly, the second law of Gossen states that in the utility-based optimum, the relation between prices of different goods is as high as the relation between the marginal utilities of these goods. Therefore in general valuation means to compare objects (Moxter, 1983, pp. 123, 130) according to their utility for the individual. The higher the additional utility of the good received, the higher is the value, and the more the buyer is willing to pay (i.e. price). (On the relation of value and price see Helbling, 1993, p. 47-49; Francis, 1986, pp. 195-203; Tichy, 1994, pp. 29-31, 104-105, and the scheme on pp. 174-177). Consequently the question arises which criteria determine the utility and the value/price of a certain good - especially a company (Born, 1995, p. 21). 


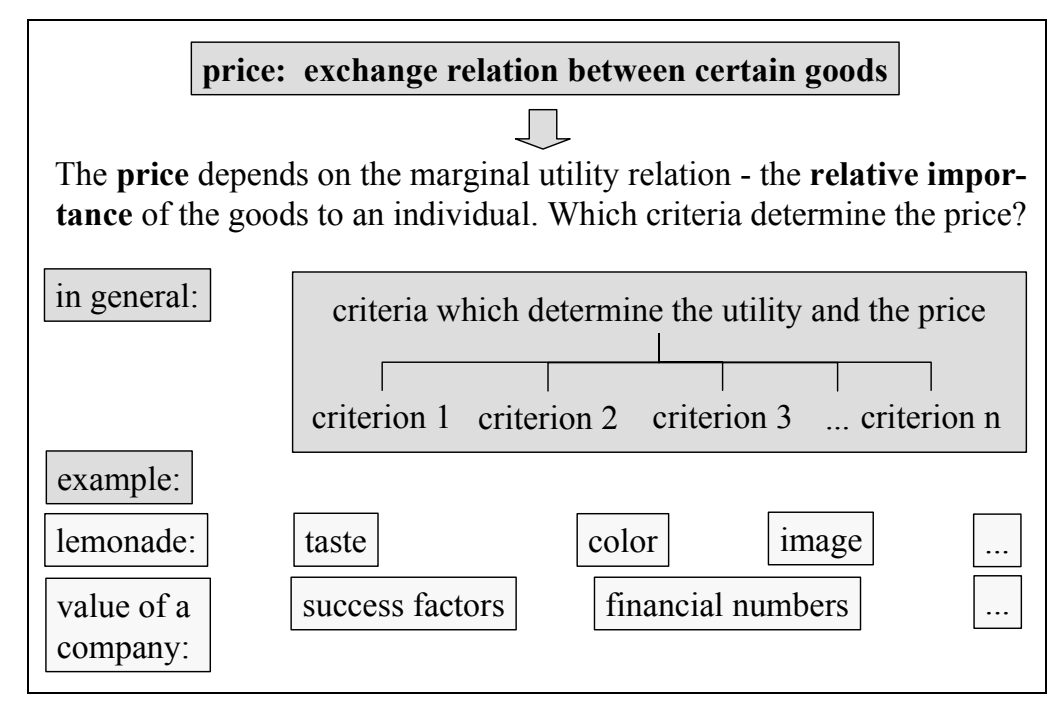

Figure 1: Price as the exchange relation between certain goods

Figure 1 shows an illustrative example for value drivers: In case of a lemonade the utility for the consumers is not only determined by the taste, but also by the colour, the image and many other criteria. For the value of a company, success factors and financial numbers are of importance. Because of the existence of different criteria, to value a company is a multicriteria decision-making problem (Bretzke, 1974, pp. 41-44; Ballwieser, 1995, column 1868; Sieben, 1969; Matschke, 1993; Hafner, 1988; Hafner, 1989).

As the price is only an exchange relation between certain goods, every valuation is concerned with relative advantages. Thus for the problem of valuation of a company it seems useful to take directly the advantages against the competitors, i.e. the competitive advantages. The existence of different success factors (Gälweiler, 1974, p. 132) is the reason for competitive advantages (Porter, 1985). The realization of competitive advantages can be seen in financial numbers at last (figure 2) (Günther, 1997, pp. 68-69). For the quality of a valuation the correct assessment of the success factors is much more important than the correct application of financial formulas (Bretzke, 1988, p. 823; Moxter, 1983, p. 125).

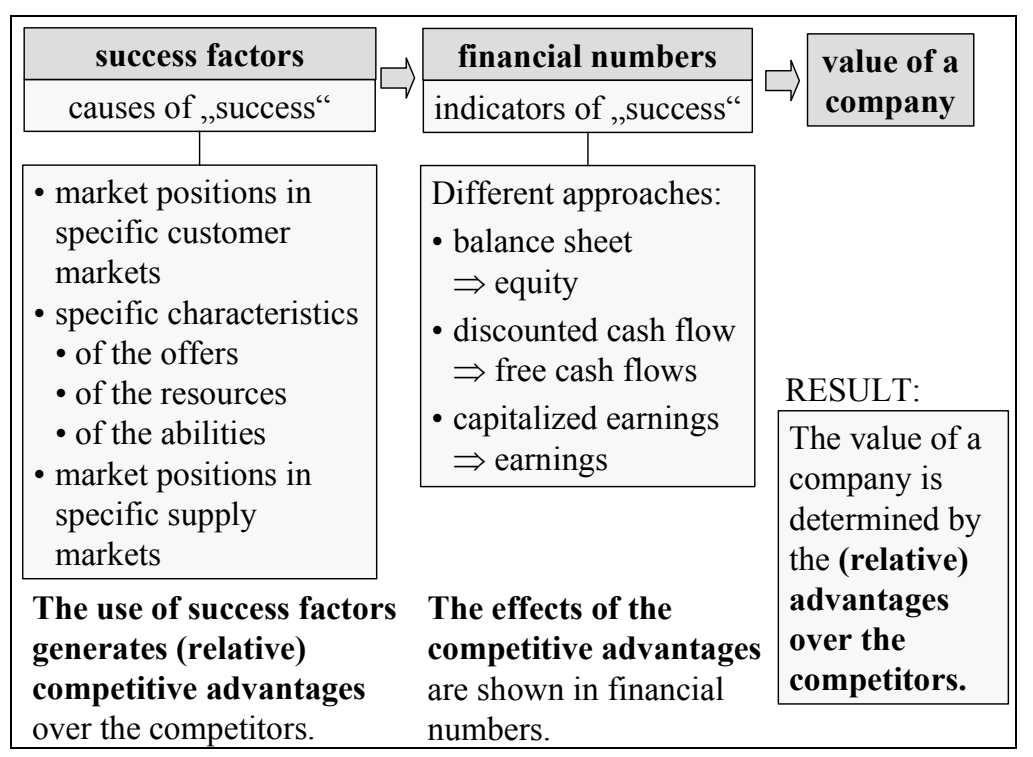

Figure 2: Causes and effects of competitive advantages 
In literature there exist several classifications of success factors - the causes for "success" (Hinterhuber, 1997, p. 61). Following Kühn and Grünig, 1998, pp. 73-75, success factors are (a) market positions in specific customer markets (market share, image of firm and brand, customer relationships, size, attractiveness and growth rate of the markets) as well as (b) specific characteristics of the offers (quality of the products, width and depth of the assortment, prices, conditions, services, marketing communication), specific characteristics of the resources (human capital, capacities, technologies, cash and cash equivalents, information systems), and abilities (competences, innovation ability, flexibility) and (c) market position in specific supply markets (supply market, relationships with suppliers) (also Moxter, 1983, pp. 102-103). The stronger these success factors and the better the use of them, the more favourable is the position of the company against its competitors, and therefore the larger is the competitive advantage. In this sense ,success“ has a long-term and hardly tangible meaning (Kühn and Grünig, 1998, p. 78).

The common approaches of valuation (Bodie, Kane and Marcus, 1996, pp. 521-522; Tichy, 1994, pp. 8687) use different financial numbers as indicators for "success":

- Balance sheet approach: The key number is the equity or "book value" according to one of several possible measurement concepts (e.g. historical cost or fair value). The total equity is the surplus of the total assets (financial assets, plant, property and equipment, intangible assets like patents, stocks of raw material and finished products, disposals on banks etc.) over the liabilities of the company.

- Discounted cash flow approach: The net surplus of the cash inflows over the cash outflows from operating activities ("cash flow" for short) that is estimated for future periods is focused. Reducing the cash flow by payments for reinvestments, which are notable to continue with the company, will give the free cash flows. (Lintner, 1962, p. 248. See also Hachmeister, 1998; Ballwieser, 1998.)

- Capitalized earnings approach: The key numbers are the estimated future earnings as the surplus of the incomes over the expenditures (Miller and Modigliani, 1961).

The methodical lack of all widely-used valuation methods is that they do not use the causes of success i.e. the success factors that generate competitive advantages -, but only indicators of the effects of competitive advantages (Tichy, 1994, pp. 21 and 81). Therefore we have to look for a way to consider both success factors and financial numbers in an integral valuation approach (Tichy, 1994, p. 174; Voigt, 1990, pp. 48-50; for the empirical relevance of an integral valuation see Amir and Lev, 1996).

\section{Determining the relative value of a company by use of the AHP-technique}

In the following paragraphs an Analytic Hierarchy Process (AHP) (Saaty, 1990) approach is used for determining the relative value of a company. This technique is applied for general multicriteria decisionmaking. As stated before, the valuation of a company is also a special multicriteria decision problem. Therefore we adopt the steps of the AHP-technique to determine the relative value of a firm (figure 3 ).

Use of the AHP-technique for valuation of a company:

1. Decompose the goal "valuation of a company" into a hierarchy of criteria (value drivers) and determine the set of competitor companies.

2. Determine the criterion weights and the relative assessments of the companies with respect to the lowest level criteria.

3. Synthesize the criterion weights over all levels of the hierarchy and calculate the total relative values for all companies according to their relative assessments.

4. If wanted: Calculate the estimates for the value of a company in monetary units.

5. Perform a sensitivity analysis.

Figure 3: Steps of valuation of a company by use of the AHP-technique 
To our knowledge in literature Hafner, 1988, is the only one who uses the AHP-technique for valuation of companies, but in Hafner, 1988, pp. 498-504, the AHP-technique is only used to calculate criterion weights for a scoring model. A comparison of different companies by use of AHP is missed.

In a concrete situation, the valuation with the AHP technique can pass through several loops of the different steps shown in figure 3 . This is often the case when the result - the relative value of a company - is subjectively felt to be false. In particular when a team makes a decision, often some individual members bring not yet mentioned criteria into the discussion of the first results. This causes a backtrack to step 1 and therefore a restart of the total procedure. In the following pages the paragraphs are organized according to the steps mentioned in figure 3 .

\subsection{Decomposing the goal "valuation of a company" into a hierarchy of criteria and determining a set of competitors}

The problem of the valuation of a company is decomposed hierarchically. The approach explicitly takes into account that success factors are the causes of different values. An integration of the financial results of the use of the success factors is also possible. Furthermore a pre-calculated value of the company as a global financial number can be taken as one (more or less) important criterion within the more general approach presented in this paper. This pre-calculated value can be the result of the application of a widely used certain financial formula, e.g. the discounted cash flow method, which only takes into account tangible free cash flows. Figure 4 shows an illustrative (not a conclusive) example for a hierarchical structure of some possible criteria.

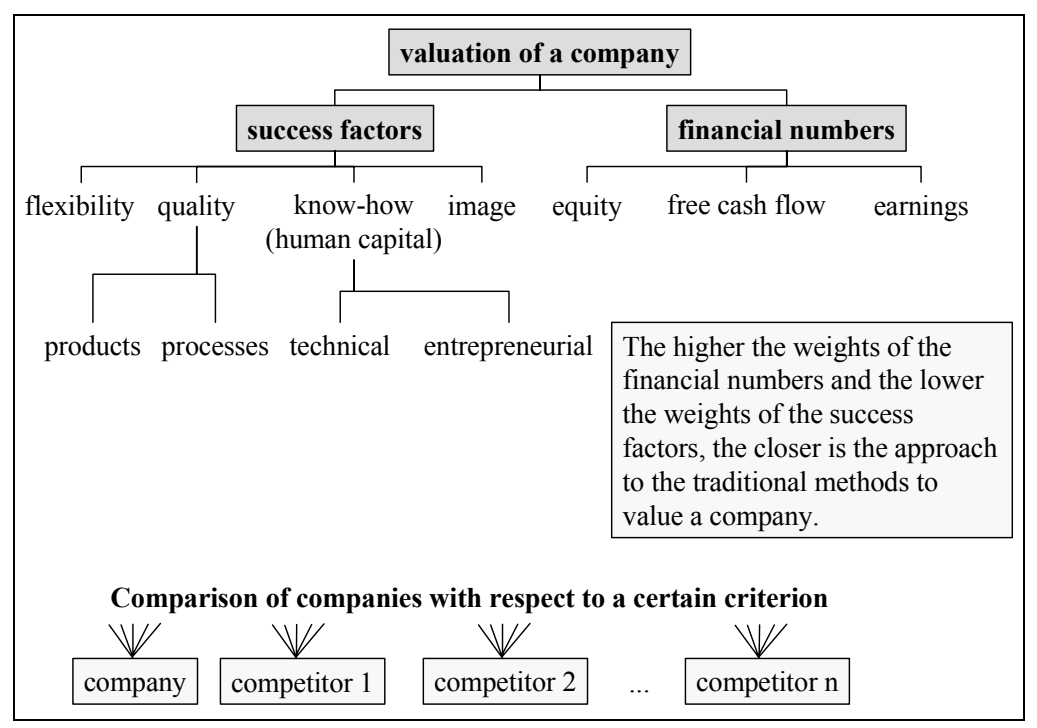

Figure 4: Illustrative example of a possible hierarchy of criteria

In this 4-level-hierarchy there are criteria groups (e.g. success factors, financial numbers), single criteria (e.g. flexibility, quality, know-how, and image within the criteria group "success factors"), and sub-criteria (e.g. technical know-how and entrepreneurial know-how within the single criteria "know-how"). If there exist dependence and feedback among the set of criteria we have to use the ANP-technique (Analytical Network Process) (Saaty, 1996) as a generalization of the AHP-technique. The set of companies (in general decision problems: the alternatives) define the lowest level of the hierarchy.

In such a hierarchy almost all fundamental approaches for the problem of valuation of a company can be included - this is merely a question of the selection and of the weighting of the criteria. Caution has to be given for the use of financial numbers. As will be shown in the following paragraph a hierarchical combination of financial numbers which are components of an aggregated financial number must be avoided. 
For the valuation of companies with the AHP technique it is further necessary to determine the set of companies included in the comparisons. With respect to the following step of the procedure we have to make the following assumptions:

- Within a certain industry the relative importance of success factors is identical for all companies.

- Within a certain industry there exist the same benchmarks for the financial numbers (current ratio, inventory turnover, ...).

Consequently the criteria and the criterion weights are identical within a certain industry. Therefore the relative valuation of a company has to be performed in comparison to at least one other company of the same industry. (For the definition and the analysis of an industry see Bodie, Kane and Marcus, 1996, p. 506-514; Francis, 1986, pp. 484-501. The key problem is to find really closely similar companies. See Damodaran, 1994, p. 373.)

\subsection{Determination of criterion weights and relative assessments of the companies}

After establishing a hierarchy of criteria and defining a set of competitor companies the problem is to determine the criterion weights and the relative assessments of the companies with respect to the criteria on the lowest level of the hierarchy. Therefore, we have to find answers to the questions that are listed in figure 5:

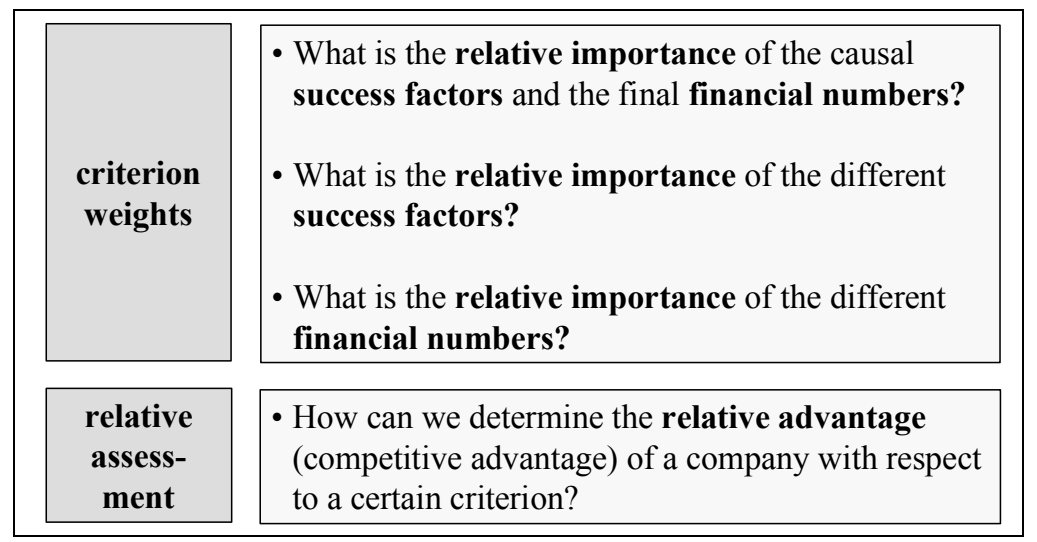

Figure 5: Questions to be answered for the relative valuation of a company

In the terminology of the AHP literature the relative importance (criterion weight, value) of elements of the hierarchy (sub-criteria, competitors) with respect to an element of the next higher level of the same hierarchy (criteria or even criteria groups) is defined as local priority. All local priorities of a single comparison sum up to 1 . They are normalized numbers on a ratio scale. The determination of local priorities is not homogenous and depends on the concrete comparison to be made. As there exist no problem-dependent calculation schemes for determining the local priorities we refer to Saaty, 1990.

The process of assessing the companies with respect to the value driving-criteria can be taken as a kind of benchmarking (Camp, 1989). Aspects which have to be taken into account while determining the industry-dependent relative importance of success factors can be found in Kühn and Grünig, 1998, pp. 166-185 (also Hinterhuber, 1997, pp. 69-117). In this paper we will now concentrate on a problem concerned with the use of financial numbers. We postulate using only aggregate financial numbers. The evidence of this postulate will be demonstrated in a conceptual example (tables 1-4) on the relative valuation of four companies. Assuming that we follow the (simple) balance sheet approach (see above) we consider to use "assets" and "liabilities" as separate criteria into the hierarchy (MU = monetary units): 


\begin{tabular}{|c||c|c|c|}
\hline company & assets [MU] & liabilities [MU] & equity [MU] \\
\hline \hline A & 9,000 & 7,000 & 2,000 \\
B & 7,200 & 6,000 & 1,200 \\
C & 8,000 & 6,400 & 1,600 \\
D & 2,000 & 1,200 & 800 \\
\hline \hline sum & 26,200 & 20,600 & 5,600 \\
\hline
\end{tabular}

Table 1: Financial numbers "assets", "liabilities", and "equity" used in the example

As "assets" is a hard criterion that is proportional to the local priorities (The larger the assets the more favourable.), the relative assessment of the companies can be calculated easily:

\begin{tabular}{|c||c|c|}
\hline company & assets [MU] & local priority \\
\hline \hline A & 9,000 & $\mathbf{0 . 3 4 4}$ \\
B & 7,200 & $\mathbf{0 . 2 7 5}$ \\
C & 8,000 & $\mathbf{0 . 3 0 5}$ \\
D & 2,000 & $\mathbf{0 . 0 7 6}$ \\
\hline \hline sum & 26,200 & 1.000 \\
\hline
\end{tabular}

Table 2: Relative assessments of the companies with respect to "assets"

The second criterion "liabilities" is also a hard criterion, but a reciprocal relationship exists between the amount of liabilies of a company and the local priority (The higher the amount of liabilities, the more unfavorable this is to the company.). In the first step we have to calculate the relation between the liabilities of all companies included into the comparison. Then we take the reciprocal of the relation numbers as basis for the determination of the local priorities. The local priorities were calculated as normalized numbers of these reciprocals. (Due to rounding errors the sum of rounded local priorities is 0.999.)

\begin{tabular}{|c||c|c|c|c|}
\hline company & liabilities [MU] & relation & reciprocal of the relation & local priority \\
\hline \hline A & 7,000 & 0.340 & 2.943 & $\mathbf{0 . 1 1 0}$ \\
B & 6,000 & 0.291 & 3.433 & $\mathbf{0 . 1 2 8}$ \\
C & 6,400 & 0.311 & 3.219 & $\mathbf{0 . 1 2 0}$ \\
D & 1,200 & 0.058 & 17.167 & $\mathbf{0 . 6 4 1}$ \\
\hline \hline sum & 20,600 & 1.000 & 26.762 & 1.000 \\
\hline
\end{tabular}

Table 3: Relative assessments of the companies with respect to "liabilities"

Considering that the excess of the assets over the liabilities is the equity of a company we also have the possibility to use directly the aggregated hard criterion "equity". Like the criterion "assets" we have a proportional relationship between "equity" and the local priority.

\begin{tabular}{|c||c|c|}
\hline company & equity [MU] & local priority \\
\hline \hline A & 2,000 & $\mathbf{0 . 3 5 7}$ \\
B & 1,200 & $\mathbf{0 . 2 1 4}$ \\
C & 1,600 & $\mathbf{0 . 2 8 6}$ \\
D & 800 & $\mathbf{0 . 1 4 3}$ \\
\hline \hline sum & 5,600 & 1.000 \\
\hline
\end{tabular}

Table 4: Relative assessments of the companies with respect to "equity" 
Neglecting other possible criteria and comparing the tables 2-4 we get the following finding: If we use the hierarchical combination we have to combine the local assessments with respect to "assets" and "liabilities" of each company to determine the relative value. Considering the assessments for company A we have to combine the local assessment 0.344 (assets) and the local assessment 0.110 (liabilities) according to the criterion weights. Using the aggregate criterion "equity" we get the relative value of 0.357 for company A. As there exists no linear combination with positive coefficients that aggregates 0.344 and 0.110 to the relative value of 0.357 - measured directly by use of the aggregate criterion "equity" -, it can be stated that the hierarchical combination is misleading in this case.

Therefore we postulate using only the highest possible aggregation level for financial numbers and any other hard criteria, if we have decided to work with these data in the AHP hierarchy. Consequently only the top number of most hierarchical value-oriented decomposition systems (for an overview see Günther, 1997, pp. 264-278) can be integrated into an AHP hierarchy; the hierarchical decomposition of this top number within an AHP hierarchy must be avoided.

\subsection{Synthesizing the assessments to the total relative value of companies}

After determining the criterion weights and the local relative assessments of the companies with respect to each of the criteria, the total relative value of a company can then be calculated by synthesizing the assessments to the overall priority. The process of synthesizing can be split up into two separate steps:

- Calculation of the total weighting coefficients: The total weighting coefficients of the lowest level criteria have to be calculated by multiplication of the local priorities over all levels in the hierarchy.

- Calculation of the total relative values of the companies: For the purpose of calculating the total relative values of the companies, the relative assessments of the companies are multiplied with the total weighting coefficients of the lowest level criteria.

As the synthesizing is independent of the problem analysed, we can refer to Saaty (1990) for short.

\begin{tabular}{|c||c|}
\hline company & total relative value $[-]$ \\
\hline \hline A & $\mathbf{0 . 2 7 5}$ \\
B & $\mathbf{0 . 2 4 2}$ \\
C & $\mathbf{0 . 2 4 7}$ \\
D & $\mathbf{0 . 2 3 6}$ \\
\hline \hline sum & 1.000 \\
\hline
\end{tabular}

Table 5: Total relative values of the companies

For illustration, as the result of the synthesizing, the relative values of the companies considered in the comparison could have been calculated as in table 5 .

\subsection{Estimation of the value of a company in monetary units}

In general, valuation (in monetary units) means that an object has to be compared with another object; the value of the considered object will be derived from the known value (price) of this other object (Moxter, 1983 , pp. 123 and 130). The additional step outlined in this paragraph only has to be performed if the value of a company should be expressed in monetary units. It is not necessary for the valuation of a company relative to its competitors - in the sense of benchmarking. It is required to know the value in monetary units of at least one competitor. This can be the market value of the total number of shares of a competitor listed at the stock exchange. The value of a company expressed in monetary units (MU) can then be calculated in the following way:

$\begin{gathered}\text { value of the com- } \\ \text { pany in MU }\end{gathered}=\begin{gathered}\text { known value of the } \\ \text { competitor in MU }\end{gathered} * \frac{\text { total relative value of the company }}{\text { total relative value of the competitor }}$


Using this Comparative Company Approach (CCA) (Mandl and Rabel, 1997, pp. $43-44$ and 259-265; Damodaran, 1994, pp. 15-16) we transform the total relative value given in table 6 into monetary units. The result is a variety of estimates presented in table 7.

\begin{tabular}{|l||c|c|c|c|}
\hline company & $\begin{array}{c}\text { total relative } \\
\text { value } \\
\text { a }\end{array}$ & $\begin{array}{c}\text { value of the } \\
\text { company } \\
\text { b }\end{array}$ & $\begin{array}{c}\text { multiplier } \\
\text { [MU] }\end{array}$ & $\begin{array}{c}\text { estimation for } \\
\text { the value of } \\
\text { company A } \\
{[\mathrm{MU}]}\end{array}$ \\
\hline \hline $\mathrm{A}$ & 0.275 & $?$ & $\mathrm{~d}=\mathrm{c} / \mathrm{b}$ & $\mathrm{e}=\mathrm{d} * 0.275$ \\
\hline $\mathrm{B}$ & 0.242 & 35,000 & 144,628 & $\mathbf{3 9 , 7 7 3}$ \\
$\mathrm{C}$ & 0.247 & 40,000 & 161,943 & $\mathbf{4 4 , 5 3 4}$ \\
$\mathrm{D}$ & 0.236 & 30,000 & 127,119 & $\mathbf{3 4 , 9 5 8}$ \\
\hline \hline Total B, C, D & 0.725 & 105,000 & 144,828 & $\mathbf{3 9 , 8 2 8}$ \\
pessimistic \\
average
\end{tabular}

Table 7: Estimates of the value of a company in monetary units

The total relative values of the companies A, B, C, and D are known just after the end of the AHP-procedure (column $b$ ). They represent the position of a company as an overall benchmark. If it is required to express the value of company A in monetary units, then it can be calculated

- $\quad$ on the basis of each other of the known monetary values of the company B, C, and D, (Hafner, 1993, pp. 88-89. The number of comparison objects defines the number of possible values of the object to be valued. See Moxter, 1983, p. 130) and/or

- on the basis of the sum of the known monetary values of the entire remaining line (capitalization of the total industry except company A).

For all different approaches the result must be an estimate, because all numbers and assessments are estimates, too. Therefore it is preferable to use a range of possible values as the result of a valuation (Tichy, 1994, p. 166; Busse von Colbe, 1957, p. 179; Ballwieser, 1990, pp. 194-195). All possible estimates are listed in table 7. The entries in column d can be interpreted as possible "multipliers" for the total relative value of company A. On average this multiplier for the industry is 144,828 . There exists a range for the estimate of the value of company A from 34,958 MU (pessimistic) to 44,534 MU (optimistic). If the capitalization of the entire remaining industry is used for calculation, then the estimate for the monetary value of company A is 39,828 MU.

\subsection{Sensitivity analysis}

In a subsequent sensitivity analysis it is possible to examine how the calculated values would change if the criterion weights would be chosen differently (The need for a sensitivity analysis already has been seen by Busse von Colbe, 1957, p. 179).

\section{Conclusion}

In this contribution an approach has been presented, which enables one to consider directly the causes for the value of a company - the existence and the use of success factors. This approach can be taken as a generalization of existent methods because it is possible to consider financial numbers as well as nonfinancial criteria. Existent valuation methods are based only on financial numbers, which show the final effects of success factors. The advantage of this approach compared to existent valuation methods is the explicit analysis of the causal value-driving success factors, which lead to competitive advantages. In this way, it reflects the idea of benchmarking as well as the nature of the value and the price, respectively, as the relative exchange relation and benefit measure for goods - here: companies. 


\section{References}

Amir, E. and Lev, B. (1996), "Value-relevance of nonfinancial information: The wireless communications industry", Journal of Accounting and Economics, 22, 3-30.

Ballwieser, W. (1998), „Unternehmensbewertung mit Discounted Cash Flow-Verfahren“, Die Wirtschaftsprüfung, 51, 81-92.

Ballwieser, W. (1995), „Unternehmensbewertung“, W. Gerke and M. Steiner (ed.): Handwörterbuch des Bank- und Finanzwesens, $2^{\text {nd }}$ edition, Stuttgart: Schäffer-Poeschel, 1867-1882.

Ballwieser, W. (1990) Unternehmensbewertung und Komplexitätsreduktion, $3^{\text {rd }}$ edition, Wiesbaden: Gabler.

Bodie, Z., Kane, A. and Marcus, A. J. (1996) Investments, $3^{\text {rd }}$ edition, Boston et al.: Irwin/McGrawHill.

Born, K. (1995) Unternehmensanalyse und Unternehmensbewertung, Stuttgart: Schäffer-Poeschel.

Bretzke, W.-R. (1974) Unternehmensbewertung und unvollkommene Information, dissertation, Universität zu Köln.

Bretzke, W.-R. (1988), „Risiken in der Unternehmensbewertung“, Zeitschrift für betriebswirtschaftliche Forschung, 40, 813-823.

Busse von Colbe, W. (1957) Der Zukunftserfolg - Die Ermittlung des künftigen Unternehmungserfolges und seine Bedeutung für die Bewertung von Industrieunternehmen, Wiesbaden: Gabler.

Camp, R. C. (1989) Benchmarking: The search for industry best practice that lead to superior performance, Milwaukee (Wis.): Quality Press/White Plains (New York).

Copeland, T. E. and Weston, J. F. (1988) Financial Theory and Corporate Policy, $3^{\text {rd }}$ edition, Reading, Massachusetts: Addison-Wesley.

Copeland, T., Koller, T. and Murrin, J. (1994) Valuation - Measuring and Managing the Value of Companies, $2^{\text {nd }}$ edition, New York et al.: John Wiley \& Sons.

Damodaran, A. (1994) Damodaran on Valuation - Security Analysis for Investment and Corporate Finance, New York et al.: John Wiley \& Sons.

Drukarczyk, J. and Schwetzler, B. (1998) Unternehmensbewertung, $2^{\text {nd }}$ edition, München: Vahlen.

Francis, J. C. (1986) Investments: Analysis and Management, $4^{\text {th }}$ edition, NewYork et al.: McGrawHill.

Gälweiler, A. (1974) Unternehmensplanung - Grundlagen und Praxis, Frankfurt: Herder und Herder.

Gossen, H. H. (1854) Entwicklung der Gesetze des menschlichen Verkehrs und der daraus fließenden Regeln für menschliches Handeln, Braunschweig: Vieweg (Reprint, Amsterdam: Liberac, 1967).

Günther, T. (1997) Unternehmenswertorientiertes Controlling, München: Vahlen, 1997.

Hachmeister, D. (1998) Der Discounted Cash Flow als Maß der Unternehmenswertsteigerung, $2^{\text {nd }}$ edition, Frankfurt am Main et al.: Lang. 
Hafner, R. (1993): „Unternehmensbewertungen als Instrumente zur Durchsetzung von Verhandlungspositionen“, Betriebswirtschaftliche Forschung und Praxis, 45, 79-89.

Hafner, R. (1989) Grenzpreisermittlung bei mehrfacher Zielsetzung - Ein Beitrag zur Bewertung strategischer Unternehmensaquisitionen, Bergisch Gladbach: Eul.

Hafner, R. (1988), „Unternehmensbewertung bei mehrfacher Zielsetzung“, Betriebswirtschaftliche Forschung und Praxis, 40, 485-504.

Helbling, C. (1993) Unternehmensbewertung und Steuern - Unternehmensbewertung in Theorie und Praxis, insbesondere die Berücksichtigung der Steuern aufgrund der Verhältnisse in der Schweiz und in der Bundesrepublik Deutschland, $7^{\text {th }}$ edition, Düsseldorf: IDW.

Hinterhuber, A. (1997) Strategische Erfolgsfaktoren bei der Unternehmensbewertung - Ein konzeptionelles Rahmenmodell, Wiesbaden: Deutscher Universitäts-Verlag.

Kühn, R. and Grünig, R. (1998) Grundlagen der strategischen Planung - Ein integraler Ansatz zur Beurteilung von Strategien, Bern/Stuttgart/Wien: Haupt.

Lintner, J. (1962), "Dividends, Earnings, Leverage, Stock Prices and the Supply of Capital to Corporations", The Review of Economics and Statistics, 44, 243-269.

Loderer, C. et al. (2000) Handbuch der Bewertung - Praktische Methoden und Modelle zur Bewertung von Projekten, Unternehmen und Strategien, Zürich: NZZ.

Mandl, G. and Rabel, K. (1997) Unternehmensbewertung - Eine praxisorientierte Einführung, Wien: Ueberreuter.

Matschke, M. J. (1993), „Einige grundsätzliche Bemerkungen zur Ermittlung mehrdimensionaler Entscheidungswerte der Unternehmung“, Betriebswirtschaftliche Forschung und Praxis, 1-24.

Miller, M. H. and Modigliani, F. (1961), "Dividend Policy, Growth, and the Valuation of Shares", The Journal of Business, 34, 411-433.

Moxter, A. (1983) Grundsätze ordnungsmäßiger Unternehmensbewertung, $2^{\text {nd }}$ edition, Wiesbaden: Gabler.

Porter, M. E. (1985) Competitive Advantage - Creating and Sustaining Superior Performance, New York: The Free Press/London: Collier Macmillan Publishers.

Saaty, T. L. (1996) Decision Making With Dependence And Feedback - The Analytic Network Process - The organization and prioritisation of complexity, Pittsburgh: RWS Publications.

Saaty, T. L. (1990) Multicriteria Decision Making - The Analytic Hierarchy Process - Planning, Priority Setting, Resource Allocation, Pittsburgh: RWS Publications.

Sieben, G. (1969), „Die Bewertung von Unternehmen auf Grund von Erfolgsplänen bei heterogenen Zielen“, W. Busse von Colbe and P. Meyer-Dohm (ed.) Unternehmerische Planung und Entscheidung, Bielefeld: Bertelsmann, 70-100.

Tichy, G. E. (1994) Unternehmensbewertung in Theorie und Praxis, Wien: Linde.

Voigt, J. F. (1990): Unternehmensbewertung und Potentialanalyse - Chancen und Risiken von Unternehmen treffsicher bewerten, Wiesbaden: Gabler. 